\title{
Estimation of Breakthrough Time on Activated Carbon Fixed Bed Adsorbers for Multicomponent Organic Solvent Vapors
}

\author{
Hajime HORI, Isamu TANAKA and Takashi AKIYAMA \\ Department of Environmental Health Engineering, Institute of Industrial Ecological Sciences, University of Occupational \\ and Environmental Health, Japan. Kitakyushu 807, Japan
}

\begin{abstract}
The estimation of breakthrough time for multicomponent organic solvent vapors on activated carbon fixed beds is significantly complicated and difficult. This paper describes a simple estimation method of breakthrough time for the first component (foremost breakthrough component) in two- or three-component organic solvent vapors on an activated carbon fixed bed. The breakthrough time for the first component was expressed by the harmonic mean value of the breakthrough times in each pure component. Estimated breakthrough times were compared with the experimental ones.
\end{abstract}

Key words: multicomponent organic solvent, activated carbon, adsorption, breakthrough time.

(Received 15 November 1986)

\section{Introduction}

In the designing of vapor adsorption devices, such as, gas masks or charcoal tubes, it is necessary to determine the life of adsorbers. Many estimation methods of breakthrough curves and breakthrough times on fixed bed adsorbers have been proposed (Carter, 1966; Wheeler \& Robell, 1969; Jonas \& Rehrmann, 1973; Nelson \& Correia, 1976; Hashimoto \& Miura, 1976; Grubner \& Burgess, 1981; Yoshida \& Ruthven, 1983; Yoon \& Nelson, 1984; Hori et al., 1985a), but most of these methods are only for the pure components. However, organic solvents used in the work environment are usually mixed solvents of several components, and the generated vapors also become multicomponent organic solvent vapors. In these cases, we have to determine the breakthrough time for the multicomponent vapors. Especially, the estimation of breakthrough time for the first component (foremost breakthrough component) in the multicomponent organic solvent vapors is very important as well as the estimation of breakthrough time for pure components.

Some estimation methods of breakthrough curves and breakthrough times for the twoand three-component vapors on fixed bed adsorbers has been proposed, for example, numerical solutions by finite differences (Carter \& Husain, 1974; Robinson \& Thomas, 1980; Morbidelli et al., 1982; Sheindorf et al., 1983) and analytical solutions by linear approximations (Miura et al., 1979; Takeuchi et al., 1979). But these methods are com- 
plicated and inconvenient for practical use because many parameters have to be determined experimentally for the estimations of breakthrough time.

We propose a simple method to estimate the breakthrough time of multicomponent organic solvent vapors on an activated carbon fixed bed, and compare the estimated values with the experimental ones.

\section{Simple Estimation Method of Breakthrough Time for the First Component}

We describe the estimation of the breakthrough time mainly in a two-component system because the method is easily applied to systems of more than two components.

If vapor 1 is adsorbed in the fixed bed as a single component, the breakthrough time $\mathrm{t}_{\mathrm{B} 1}$ is shown as follows (Hori et al., 1983):

$$
\mathrm{t}_{\mathrm{B} 1}=\frac{\rho_{\mathrm{b}} \mathrm{q}_{01}}{\mathrm{uC}_{01}}\left(\mathrm{Z}-\mathrm{f}_{\mathrm{l}} \mathrm{Z}_{\mathrm{al}}\right)=\frac{\mathrm{q}_{\mathrm{el}}}{\mathrm{QG}_{01}} \mathrm{~W}
$$

Similarly, the breakthrough time for the vapor $2, \mathrm{t}_{\mathrm{B} 2}$, is:

$$
\mathrm{t}_{\mathrm{B} 2}=\frac{\rho_{\mathrm{b}} \mathrm{q}_{02}}{\mathrm{u \textrm {C } _ { 0 2 }}}\left(\mathrm{Z}-\mathrm{f}_{2} \mathrm{Z}_{\mathrm{a} 2}\right)=\frac{\mathrm{q}_{\mathrm{e} 2}}{\mathrm{QC}_{02}} \mathrm{~W}
$$

where, $\rho_{\mathrm{b}}$ : bed density $\left(\mathrm{g} / \mathrm{cm}^{3}\right)$, u: gas velocity $(\mathrm{cm} / \mathrm{min}), \mathrm{q}_{0}:$ maximum adsorption capacity $(\mathrm{g} / \mathrm{g}), \mathrm{q}_{\mathrm{e}}$ : effective adsorption capacity $(\mathrm{g} / \mathrm{g}), \mathrm{C}_{0}$ : inlet vapor concentration $(\mathrm{g} /$ $\left.\mathrm{cm}^{3}\right)$, $\mathrm{Z}$ : bed length $(\mathrm{cm}), \mathrm{Z}_{\mathrm{a}}$ : adsorption zone length $(\mathrm{cm}), \mathrm{f}$ : ratio of residual adsorption capacity in adsorption zone (-), Q: gas flow rate $(\mathrm{ml} / \mathrm{min}), \mathrm{W}$ : weight of activated carbon $(\mathrm{g})$, subscript 1 : for the vapor 1,2 : for the vapor 2 .

When the above described two vapors are mixed and introduced into the fixed bed adsorber, we assume that each vapor is adsorbed on different parts of the activated carbon fixed bed. This assumption indicates that vapor 1 is adsorbed on $W_{1}$ in the bed and vapor 2 is adsorbed on the remainder, i.e., $W-W_{1}$, at the breakthrough time of the first component $t_{B}$. In addition, each region is assumed to have the same adsorption capacity as the case of the adsorption of the pure component vapor. Under these assumptions, the mass balance of each component is shown as Eqs. (3) and (4).

$$
\begin{aligned}
& \mathrm{QC}_{01} \mathrm{t}_{\mathrm{B}}=\mathrm{q}_{\mathrm{e} 1} \mathrm{~W}_{1} \\
& \mathrm{QC}_{02} \mathrm{t}_{\mathrm{B}}=\mathrm{q}_{\mathrm{e} 2}\left(\mathrm{~W}-\mathrm{W}_{1}\right)
\end{aligned}
$$

where, $t_{B}$ is breakthrough time of the first component.

Calculating W from Eqs. (3) and (4), and substituting W into Eqs. (1) and (2), $t_{B}$ is obtained as follows: 


$$
t_{B}=\frac{1}{1 / t_{B 1}+1 / t_{B 2}}
$$

Equation (5) shows that the breakthrough time for the first component in the twocomponent system is expressed by the harmonic mean of the breakthrough time of each pure component. This equation suggests that if the breakthrough time of one component is very long, this term can be neglected. Generally, the breakthrough time becomes longer as the vapor concentration decreases. Therefore, when the vapor concentration of one component is very low, the effect of this component in Equation (5) is so small that the breakthrough time $t_{B}$ is close to that of the other pure component.

In the case of the more than two-component system, we used the same assumptions as for the two-component system. Breakthrough time of the first component in the $\mathrm{n}$-component system is shown as follows:

$$
t_{B}=\frac{1}{\sum_{i=1}^{n}\left(1 / t_{B i}\right)}
$$

If the value of the breakthrough time for the pure component can be obtained, the breakthrough time for the first component in the multicomponent vapor can also be estimated by Equation (6).

\section{Experimental}

\section{Experimental Method}

Pittsburgh activated carbon particles (12/30 mesh) were pre-treated at a temperature of $250^{\circ} \mathrm{C}$ for 24 hours under a nitrogen gas flow. The activated carbon was packed in a glass column (diameter 10 and $20 \mathrm{~mm}$ ), and air containing two- or three-components of organic solvent vapors was introduced into the column. Each vapor concentration was kept constant by a developed generator (Hori et al., 1984). The outlet gas was automatically sampled at intervals of 3 to 12 minutes, and its concentration was measured by FID-gas chromatograph (Shimadzu GC-6A, Gasukuro Kogyo Model 370). Breakthrough time was defined as the time when the outlet vapor concentration of the first component became the $10 \%$ inlet value of the first component.

The solvents were selected from those listed in Table 1, which are usually used in the work places. Experimental and analytical conditions were the same as those in our previous papers (Hori et al., 1985b; Hori et al., 1985a). 
Table 1. Organic solvents used in this experiment

\begin{tabular}{rlr}
\hline No. & \multicolumn{1}{c}{ Solvent } & $\begin{array}{c}\text { Saturate vapor } \\
\text { pressure at } 20^{\circ} \mathrm{C}^{*} \\
(\mathrm{mmHg})\end{array}$ \\
\hline 1 & Benzene & 72.4 \\
2 & Toluene & 21.8 \\
3 & O-Xylene & 6.2 \\
4 & Methanol & 96.8 \\
5 & Ethanol & 43.6 \\
6 & 2-Propanol & 32.4 \\
7 & 1-Butanol & 5.6 \\
8 & 2-Butanol & 9.0 \\
9 & 1-Pentanol & 1.8 \\
10 & 3-Methyl-1-butanol & 1.6 \\
11 & Methyl acetate & 170.2 \\
12 & Ethyl acetate & 74.4 \\
13 & Propyl acetate & 24.9 \\
14 & Isopropyl acetate & 47.9 \\
15 & Butyl acetate & 8.0 \\
16 & Isobutyl acetate & 15.0 \\
17 & Pentyl acetate & 3.0 \\
18 & Isopentyl acetate & 3.8 \\
19 & Dichloromethane & 346.0 \\
20 & 1, 2-Dichloromethane & 60.2 \\
21 & Ghloroform & 159.3 \\
22 & 1, 1, 1-Trichloroethane & 101.0 \\
23 & Carbon tetrachloride & 92.1 \\
24 & Chlorobenzene & 9.1 \\
25 & Acetone & 307.0 \\
26 & Methyl ethyl ketone & 71.2 \\
27 & Methyl isobutyl ketone & 15.5 \\
28 & Hexane & 121.0 \\
29 & Gyclohexane & 77.5 \\
\hline
\end{tabular}

* Calculated by Antoine equation (The Chemical Society of Japan, 1984)

\section{Experimental Results}

Figure 1 and 2 show typical examples of breakthrough curves for the two- and three-component system, respectively. The breakthroughs did not begin simultaneously, and the maximum value of the outlet vapor concentration, $\mathrm{C}$, except the last breakthrough component became higher than the inlet vapor concentration, $\mathrm{C}_{0}$. In our experiment, a component which had a higher saturate vapor pressure tended to break earlier with a few exceptions, such as, the hexane-cyclohexane system and methyl ethyl ketone-ethyl acetate system.

The experimental $10 \%$ breakthrough times of the first component in the two- and three-component systems are shown in the last column of Table 2 and Table 3, respectively.

\section{Discussion}

To estimate the $10 \%$ breakthrough time of the first component in the two- or threecomponent systems by using Equation (6), the value of the $10 \%$ breakthrough time of 


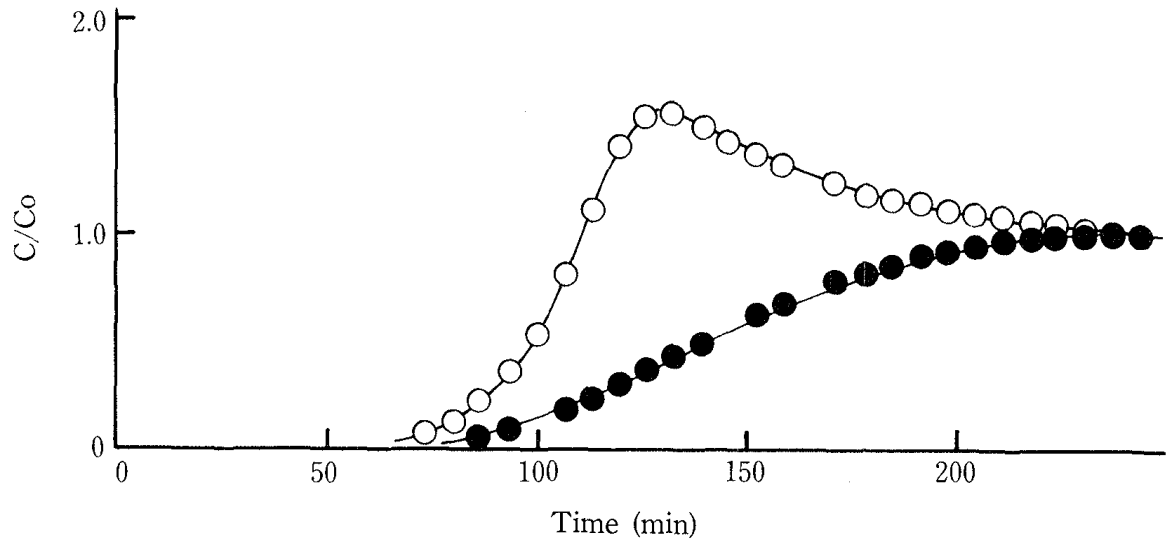

Fig. 1. An example of breakthrough curves for two-component system.

Column diameter, $\mathrm{D}=20 \mathrm{~mm}$, Gas flow rate, $\mathrm{Q}=1.52 \ell / \mathrm{min}$, Amount of activated carbon, $\mathrm{W}=4 \mathrm{~g}$

: Methyl isobutyl ketone, Concentration, $\mathrm{C}_{01}=1850 \mathrm{ppm}$,

: Butyl acetate, Concentration, $\mathrm{C}_{02}=1730 \mathrm{ppm}$.

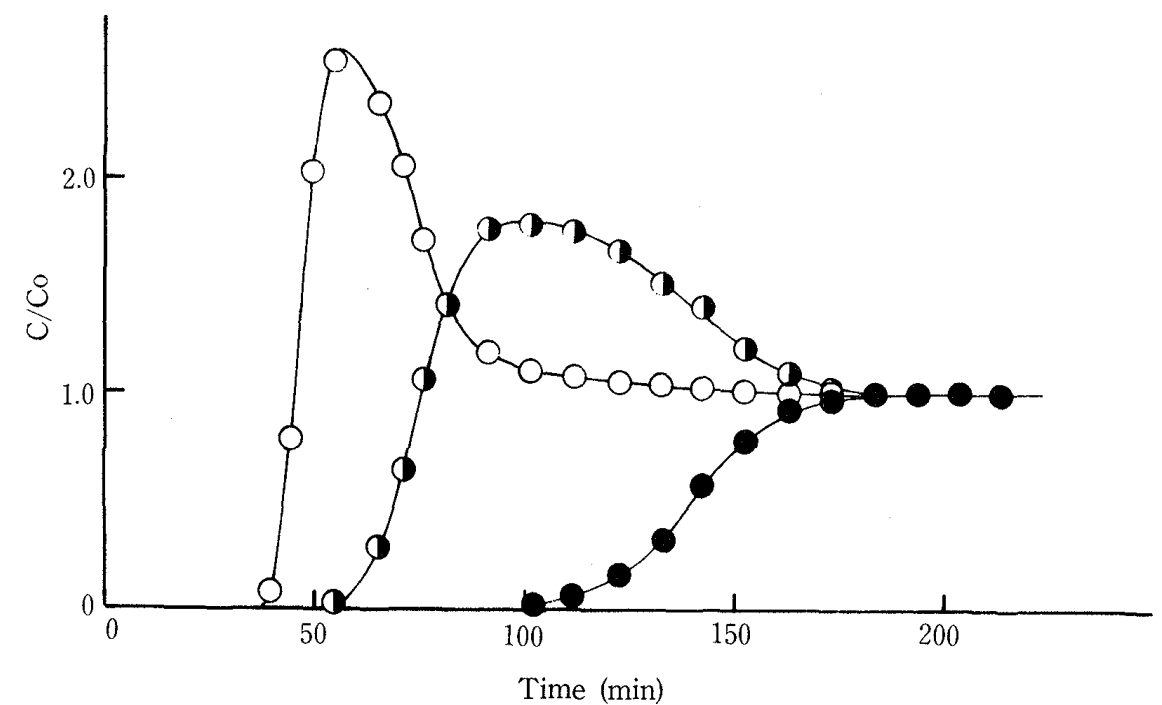

Fig. 2. An example of breakthrough curves for three-component system.

Column diameter, $\mathrm{D}=20 \mathrm{~mm}$, Gas flow rate, $\mathrm{Q}=1.45 \ell / \mathrm{min}$, Amount of activated carbon, $\mathrm{W}=4 \mathrm{~g}$

$\bigcirc:$ Methyl acetate, Concentration, $\mathrm{C}_{01}=1800 \mathrm{ppm}, \quad$ : Ethyl acetate, Concentration, $\mathrm{C}_{02}=1610 \mathrm{ppm}$. : Propyl acetate, Concentration, $\mathrm{C}_{03}=1340 \mathrm{ppm}$.

each pure component vapor is necessary. Many estimation methods of breakthrough time have been proposed for the pure component, as mentioned before. In our calculation, we used the estimation method by Hori et al. (1985a).

Table 2 shows the experimental conditions and comparison of experimental $10 \%$ breakthrough times and the calculated ones for the two-component system. In this table, column 1 and column 2 show the kinds of solvents listed in Table 1 and the solvent's vapor concentration for the first component, and column 4 and column 5 show 


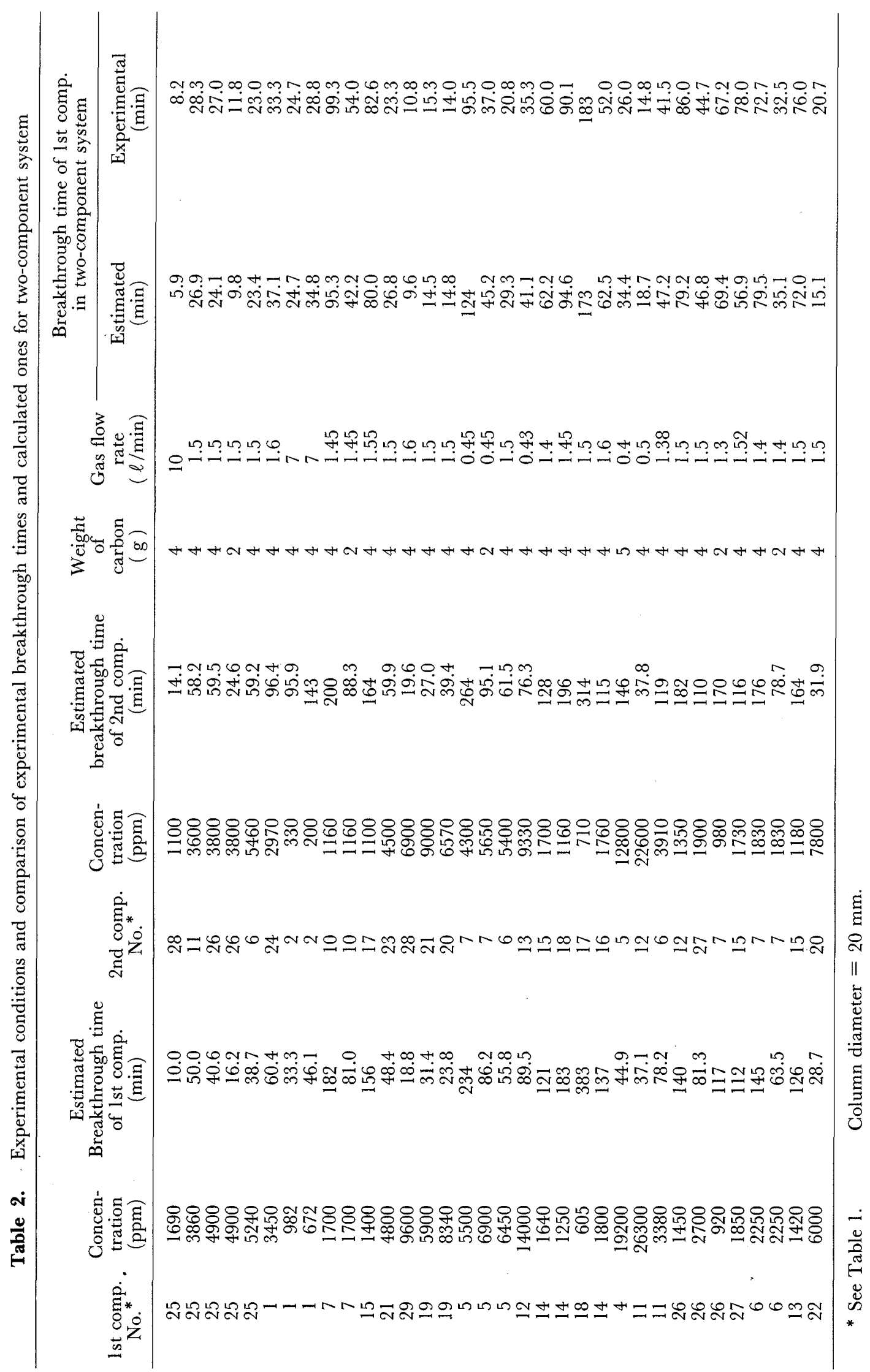




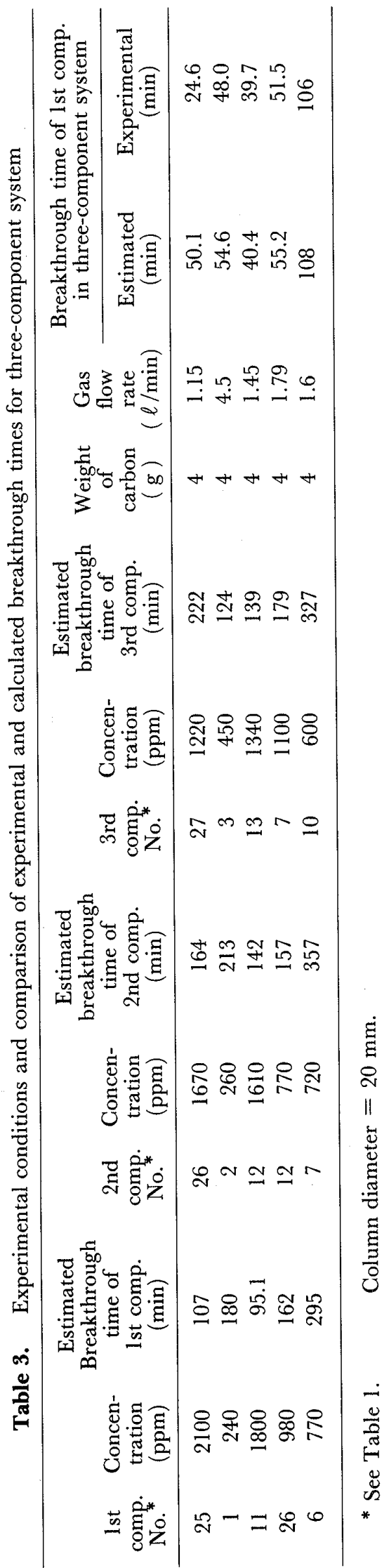


those for the second component, respectively. Column 3 and column 6 represent the estimated $10 \%$ breakthrough time when the solvent is adsorbed in the bed as a pure single component. Substituting these values into Equation (6), the $10 \%$ breakthrough times of the first component vapor in the two-component system were obtained. The estimated breakthrough times are shown in column 9 and the experimental values are also shown in the last column. Generally, the former agree well with the latter. The root square mean deviations of estimated breakthrough time for the two-component systems are $16.7 \%$, which are almost the same as the deviations for the pure component system (Hori et al., 1985a). However, the deviations are relatively large for some systems containing alcohols, such as, the ethanol-2-propanol system or the methanol-ethanol system, and systems which have shorter breakthrough times, such as, the acetone-hexane system. One reason for this is that the accuracy for the pure component is relatively poor for these compounds (Hori et al., 1985a). If we could estimate the breakthrough times for the pure component more accurately, these deviations may be reduced.

Table 3 shows the results for the three-component system. The breakthrough time of the first component can also be calculated in the same way as those for the twocomponent system. The estimated values agree well with experimental values except for the acetone-methyl ethyl ketone-methyl isobutyl ketone system.

The shape of breakthrough curves for the multicomponent system are different from those for the pure component. For example, the maximum outlet vapor concentrations exceed inlet values except for the last breakthrough component as are shown in Fig. 1 and Fig. 2. The shape of curves depend on the combination of solvent vapors. Even the same combination of vapor systems vary with the vapor concentrations, adsorption column length, and mixing ratio of solvent vapors. This fact suggests that there exist some interactions between different kinds of vapor molecules, and the weaker adsorption affinity component is desorbed and replaced by stronger affinity components. The proposed method assumes no interaction between them. If the interaction is strong, the model has to be corrected. The results of Tables 2 and 3 suggest that the interaction is considerably small for the estimation of breakthrough time.

The proposed method makes it simple to estimate the breakthrough time for the first component of multicomponent organic solvent vapors. This estimation method should prove useful in future investigations.

\section{References}

Carter, J. W. (1966): A numerical method for prediction of adiabatic adsorption in fixed beds. Trans. Instn. Chem. Engrs., 44: T253-T259.

Carter, J. W. \& Husain, H. (1974): The simultaneous adsorption of carbon dioxide and water vapour by fixed beds of molecular sieves. Chem. Eng. Sci:, 29: 267-273.

Grubner, O. \& Burgess, W. A. (1981): Calculation of adsorption breakthrough curves in air cleaning and sampling devices. Environ. Sci. Technol., 15: 1346-1351. 
Hashimoto, K. \& Miura, K. (1976): A simplified method to design fixed bed adsorbers for the Freundlich isotherm. J. Chem. Eng. Jpn., 9: 388-392.

Hori, H., Tanaka, I. \& Akiyama, T. (1983): Adsorption characteristics of organic solvent vapors on the fixed bed of activated carbon. Jpn. J. Ind. Health, 25: 356-366.

Hori, H., Tanaka, I. \& Akiyama, T. (1984): A generator for producing multicomponent organic solvent vapor in inhalation chambers. Jpn. J. Ind. Health, 26: 510-517.

Hori, H., Tanaka, I. \& Akiyama, T. (1985a): A simple estimation method of breakthrough time on fixed bed adsorption column of activated carbon. Nippon Kagaku Kaishi, 1985: 961-970.

Hori, H., Tanaka, I. \& Akiyama, T. (1985b): A simple estimation method of breakthrough time for multicomponent organic solvent vapors on activated carbon fixed bed adsorbers. Nippon Kagaku Kaishi, 1985: 2087-2093.

Jonas, L. A. \& Rehrmann, J. A. (1973): Predictive equations in gas adsorption kinetics., Carbon, 11: 59-64.

Miura, K., Kurahashi, H. Inokuchi, Y. et al. (1979): A method for calculating breakthrough curves of bicomponent fixed bed adsorption under constant pattern and linear driving force. J. Ghem. Eng. Jpn., 12: 281-288.

Morbidelli, M., Servida, A, Storti, G. et al. (1982): Simulation of multicomponent adsorption beds. Model analysis and numerical solution. Ind. Eng. Chem. Fundam., 21: 123-131.

Nelson, G. O. \& Correia, A. N. (1976): Respirator cartridge efficiency studies: VIII. Summary and conclusions. Am. Ind. Hyg. Assoc. J., 35: 514-525.

Robinson, K. S. \& Thomas, W. J. (1980): The adsorption of methane/ethane mixtures on a molecular sieve. Trans. Instn. Chem. Engrs., 58: 219-227.

Sheindorf, G., Rebhun, M. \& Sheintuch, M. (1983): Prediction of breakthrough curves from fixed bed adsorbers with Freundlich-type multisolute isotherm. Chem. Eng. Sci., 38: 335-342.

Takeuchi, T., Suzuki, Y. \& Furuya, E. (1979): On the break time and concentration distribution in multicomponent fixed-bed adsorption when constant pattern is established. J. Chem. Eng. Jpn., 12: 486-488.

The Chemical Society of Japan (1984): Kagaku Binran Kisohen II. 2nd ed. Maruzen, Tokyo. pp. 111132.

Wheeler, A. \& Robell, A. J. (1969): Performance of fixed bed catalytic reactors with poison in the bed. J. Catalysis, 13: 299-305.

Yoon, Y. H. \& Nelson, J. H. (1984): Application of gas adsorption kinetics. Am. Ind. Hyg. Assoc. J., 45: $509-516 ; 517-524$.

Yoshida, H. \& Ruthven, D. M. (1983): Dynamic behavior of an adiabatic adsorption column-I Analytic solution for irreversible adsorption. Ghem. Eng. Sci., 38: 877-884. 
混合有機溶剤蒸気の活性炭固定層に対する破過時間の推算

保利 一・田中 勇武 - 秋山 高

产業医科大学産業生態科学研究所労㗢衛生工学教室

要 旨： 作業環境中で発生する有機溶剤蒸気は数種の溶剤の混合蒸気であることが多い.このよう な作業場所において防毒マスクなどの吸着剤を使用する場合には，混合蒸気に対する破過 時間を知る必要がある．本報では，2-3成分の有機溶凨蒸気を活性炭固定層に吸着させ た場合の破過時間の簡易推算法について検討した，それぞれの溶剤は活性炭の異なる部分 に吸着し，各々の場所に扔ける吸着容量は純成分の值に等しいと仮定すると，最初に破過 する成分の破過時間は, 各々の溶剤蒸気が単独で吸着する場合の破過時間の調和平均值で 表わすことができた，この式から得られた破過時間の推算値と曾験値とは，概ね良好な一 致を示した.

J. UOEH（产業医大誌），9（1 ）:9-18 (1987) 